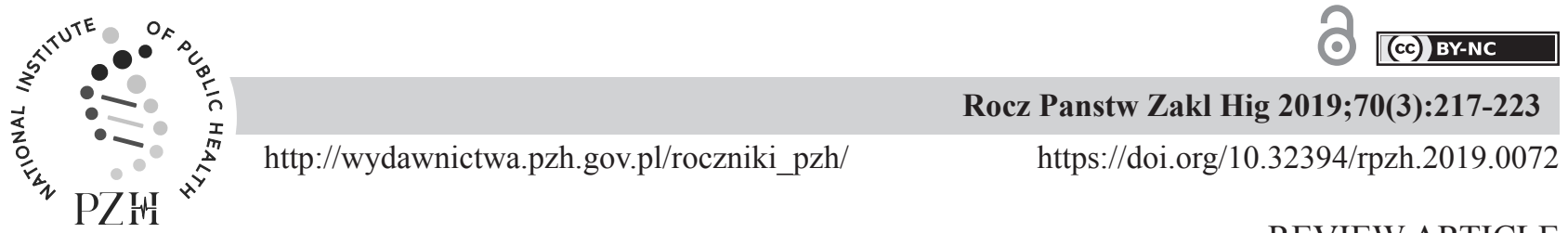

REVIEW ARTICLE

\title{
NUTRITION OF VEGETARIANS IN POLAND - A REVIEW OF RESEARCH
}

\author{
Paulina Skorek ${ }^{1}$, Pawet Glibowski ${ }^{1}$ Katarzyna Banach ${ }^{1}$
}

${ }^{1}$ Department of Biotechnology, Microbiology and Human Nutrition, University of Life Sciences in Lublin, Poland

\begin{abstract}
The first mention of a vegetarian diet in Poland appeared in the 19th century. Since then, its popularity has been growing steadily year by year. Nevertheless, it remains a controversial topic. Many scientists try to explain what is the correct vegetarian diet and how its use can affect the health and proper human body functioning. Vegetarian diet is mainly based on the elimination of meat consumption. Depending on the type, it also involves the abandonment of fish, eggs as well as milk and their products. Such kind of nutrition based mainly on plant-derived products can effectively prevent diseases of civilization, reduce the risk of developing obesity, promote the maintenance of normal cholesterol and blood sugar, and lower blood pressure. However, an incorrectly balanced vegetarian diet may be associated with deficiencies of some vitamins and minerals. This paper reviews a few dozens of studies on people using a vegetarian diet in Poland. This review shows that vegetarians in Poland are not very well studied group and further research is needed.
\end{abstract}

Key words: vegetarian diet, vegan diet, vitamin B12, supplementation, metabolic diseases, cardiovascular diseases

\section{STRESZCZENIE}

Pierwsze wzmianki dotyczące diety wegetariańskiej w Polsce ukazały się w XIX wieku. Od tamtej pory z roku na rok jej popularność stale rośnie. Pomimo to w dalszym ciągu pozostaje tematem kontrowersyjnym. Wielu polskich naukowców stara się wyjaśnić czym jest prawidłowa dieta wegetariańska oraz sprawdzić jak jej stosowanie może wpłynąć na stan zdrowia i rozwój człowieka. Dieta wegetariańska opiera się głównie na eliminacji spożycia mięsa. W zależności od rodzaju, wiąże się również z rezygnacją jedzenia ryb, jaj oraz mleka i jego przetworów. Sposób odżywiania opierający się głównie na produktach pochodzenia roślinnego w skuteczny sposób może stanowić profilaktykę chorób cywilizacyjnych, obniżać ryzyko rozwoju otyłości, sprzyjać utrzymaniu prawidłowego poziomu cholesterolu oraz cukru we krwi, a także obniżać ciśnienie tętnicze. Jednak nieprawidłowo zbilansowana dieta wegetariańska może wiązać się z niedoborami witamin i składników mineralnych. W pracy dokonano przeglądu kilkudziesięciu badań dotyczących osób stosujących dietę wegetariańską w Polsce. Przegląd ten pokazuje, że wegetarianie w Polsce stanowią grupę, która nie została jeszcze dobrze zbadana i potrzebne są dalsze badania.

Słowa kluczowe: dieta wegetariańska, dieta wegańska, witamina B12, suplementacja, choroby metaboliczne, choroby układu krążenia

\section{INTRODUCTION}

The vegetarian diet has existed since the dawn of time. It was associated with the first followers of Jainism, Buddhism and Hinduism. At the beginning of the 19th century, the first vegetarian association was established in England - The Vegetarian Society. In Poland, the first mention of a plant diet appeared in the "History of the Jarski Movement in Poland" from 1912 [13].

The popularity of vegetarian diet increases year by year. In $2000,1 \%$ of Polish people declared as vegetarians, today - already $3.7 \%$, with almost $10 \%$ among people aged 25-34 [20,43]. The change in diet could have been related as a result from various motivations: economic, religious, cultural, ethical and ecological. More and more people decide to change their nutrition style due to its positive impact on health [37]. Many studies confirm the health effect of vegetarian diet towards the prevention of civilization diseases: cardiovascular diseases, diabetes, obesity [1, $16,25,32,38]$. Despite many advantages, improper use of a vegetarian diet may have negative consequences. As a result of improper use of the diet, there may be significant deficiencies of macronutrients, minerals and vitamins, which will be associated with abnormal development and functioning of the body and the development of diseases and dysfunctions of organs.

Corresponding author: Paulina Skorek, Katedra Biotechnologii, Mikrobiologii i Żywienia Człowieka, Uniwersytet Przyrodniczy w Lublinie, ul. Skromna 8, 20-704 Lublin, Poland tel.: +48 782616 725, e-mail: paulinaskorek1@wp.pl

(C) Copyright by the National Institute of Public Health - National Institute of Hygiene 
The aim of this article was to review researches concerning the vegetarian diet of Polish people and its impact on their health. Besides, we assessed Poles' awareness of the use of vegetarian diet in a proper way.

\section{COMPARISON OF VEGETARIAN DIET AND TRADITIONAL NUTRITION}

There is a similar way of consumption among Poles, with a high consumption of meat and animal fats. Our diet is dominated by carbohydrates, in particular way by sugar and highly processed products. There is not sufficient intake of vegetables, fruits, vegetable oils, seeds and nuts [29]. Long-term usage of such diet can be associated with the occurrence of many diseases, such as obesity, cardiovascular disease and cancer. It is believed that a properly balanced diet not only works for prevention, but can also effectively support the pharmacological treatment of these diseases. Properly selected diet can bring benefits to the condition of the body, well-being and health [7]. Comparing vegetarian diets to traditional nutrition, it is possible to indicate a lot of differences in terms of energy value, macroand micronutrients supply.

The main rule of using vegetarian diets is the total elimination of meat (Table 1). Depending on the type of diet, they also give up fish, eggs, milk and its products. Vegetarian diets can be divided into lacto-ovo-vegetarian diet, ovovegetarian diet, lactovegetarian diet, semi-vegetarian diet, vegan diet, fruitarian and raw vegetarian diets [35].

Traczyk et al. [39] carried out a study on 107 vegetarians and 35 subjects who have been eating in a traditional way. Until the study, vegetarians used plant diets for an average of 5.5 years. The authors applied the method of nutritional interview carried out with each of the subjects. The results showed that the food portions of vegetarians are characterized by a much larger mass, in comparison to subjects with the traditional way of eating. Both groups consumed a lot of proteins but in the vegetarian diet legumes were definitely more abundant. They consumed almost $1500 \mathrm{~g}$ of vegetables a day, with the recommended daily intake of fruit and vegetables approx. $700 \mathrm{~g}$. It was also observed that subjects who ate in a traditional way, they consumed two times more "sugar and sweets" products as compared to vegetarians who limited the consumption of highly processed products. Instead of sweets, they tried to choose snacks such as cereal flakes, dried fruit, fruit and vegetables. Both groups also consumed comparable amounts of fat. More than $90 \%$ of fats in the vegetarians' diet were fats of vegetable origin, while in the case of people who ate in a traditional way, it was only $13 \%$. Non-vegetarian diet also contained large amounts of cholesterol. Vegetarian food rations contained a significant quantity of non-heme iron. In the vegetarian diet, the factor affecting the proper absorption of iron is the intake of large amounts of vitamin $\mathrm{C}$, which is located in vegetables and fruits. In both groups, the demand for calcium has not been fully covered [39]. A similar conclusion was made by Król et al. who compared menus from 24-hour interviews of two groups, with a traditional and a vegetarian diet. They found that a vegetarian diet delivers smaller quantities of sodium and higher quantities of iron as well as magnesium when compared to traditional nutrition. It is worth noting that the studied vegetarians used the supplementation of iron and magnesium. The supply of calcium and zinc in both diets was not enough to provide the recommended demand (Table 2)[18].

Many people believe that the elimination of food of animal origin is associated with the deficiency of important nutrients, which can worsen health [31]. Pyrzyńska carried out a survey among 100 subjects using a vegetarian diet to check whether the way in which vegetarians eat is consistent with the principles of rational nutrition. She noticed that vegetarians made nutritional mistakes. Less than half of the respondents consumed vegetables and fruit for each meal. It is worth noting that the respondents noticed a positive change in well-being since they changed their way of feeding. Quite a large group of respondents used the lacto-ovovegetarian and semi-vegetarian diet. Summing up the study, the author pointed out that semi-vegetarian diet is the most similar nutritional model for traditional nutrition [29].

Interesting research results were obtained by Czyżewska-Majchrzak et al. who carried out a study on three groups of women: experienced lacto-ovovegetarians using this diet for three years, previously eating in a traditional way, which for 5 weeks changed the nutrition to lacto-ovo-vegetarian diet and control group using traditional diet. Initially, the menus of experienced lacto-ovo-vegetarians were compared with the control group (subjects eating in a traditional way). There has been a higher intake of vitamin $\mathrm{E}$ and fiber by vegetarians. The menus of experienced lactoovo-vegetarians for testing this type of diet were also compared. The differences were related to the lower amount of energy, fat, fiber, sodium, calcium, iron, magnesium, zinc, vitamin $\mathrm{E}, \mathrm{B}$ vitamins (thiamine and niacin) and polyunsaturated fatty acids in the diet of the "new" lacto-ovo-vegetarians. Researchers concluded that a short-term change in dietary habits from a traditional diet to a lacto-ovo-vegetarian diet by people who have no previous experience in planning vegetarian meals may result in insufficient supply of many nutrients, especially calcium, magnesium, iron and $\mathrm{B}$ vitamins. This results mainly due to the fact that these people did not know how to compose a properly balanced vegetarian diet [7]. This thesis was confirmed 
by a survey carried out by scientists from the Gdańsk Maritime University, whose aim was to assess knowledge about vegetarian diets. The subjects were both vegetarians and those who eat in the traditional way. Based on the analysis of the results collected from the questionnaires, it was noted that the majority of respondents from both groups confirmed the fact that an improperly balanced vegetarian diet causes negative health effects. However, when respondents were asked to choose a meal that they believe is the best balanced in terms of the principles of a vegetarian diet, the vast majority of subjects using the traditional diet could not answer this question [35]. It is, therefore, worthwhile to educate people willing to start a vegetarian diet and provide them the appropriate dietitian help [7].

\section{STATUS OF NUTRIENTS IN THE VEGETARIAN DIET}

Vegetarianism is still considered by the majority of Poles as an incorrect diet. In a survey carried out by Śliwińska et al. on 82 subjects using traditional diet, almost half of them did not consider a vegetarian diet to be beneficial to health [35]. In fact, an unbalanced diet, although rich in vegetables and fruits, and poor in animal products can have a detrimental effect on health. Mainly a vegan diet is considered to be one that causes shortages of essential nutrients. Chabasinska et al. carried out a study aimed at assessing the effect of the type of diet and the length of its use on the serum concentration of vitamin B12. It was shown that in subjects using vegetarian diet for more than five years, the vitamin concentrations were significantly lower compared to vegetarians who used diet for a shorter time and a control group of subjects on a traditional diet. The lowest concentrations of vitamin B12 in the serum were observed in subjects using the most restrictive - lacto-vegetarian and vegan - diets [4].

In another research about vitamin B12 in vegan subjects, Madry et al., described a five-year study carried out in order to check how the use of a vegan diet can affect the serum concentration of vitamin B12 in subjects who previously fed in the traditional way. Subjects participating in the study started using a vegan diet and were divided into two groups: the first with subjects who were supposed to use a diet based only on natural products, while the second, subjects who consumed food enriched with vitamin B12. All subjects used specific nutritional patterns for five years without supplementation. After 60 months, a decrease in vitamin B12 concentration was observed in both groups, however, the group of vegans based only on natural products was significantly more deficient in this vitamin [19]. In a similar study carried out by the Ambroszkiewicz et al., lower concentrations of vitamin B12 in the vegan serum were also determined.
In lacto-ovo-vegetarians, lactovegetarians and ovovegetarians, there was no significant deficit of this vitamin [2]. In order to avoid dangerous shortages in a vegan diet, the researchers concluded that it is worth to include fortified food products $[4,19]$. Sicińska and Cholewa reviewed the enriched products with vitamin B12, available in the most popular stores in Poland. They found 220 products, of which the largest group were cereals, juices and nectars. For example, they estimated that drinking one glass of enriched apple juice effectively supply $12.5 \%$ vitamin B12 daily requirement [29]. Authors conclude that in addition to fortified products, it is also worth to remember about adequate supplementation, systematic control of serum vitamin levels and supporting with a dietitian advise, which would significantly reduce the risk of vitamin B12 deficiency [4, 19].

A shortage of key vitamins including B12 and folic acid may be associated with increased levels of homocysteine in the blood [21]. Homocysteine is a sulfuric amino acid that is formed as a result of methionine metabolism. With the proper functioning of metabolic pathways, homocysteine is re-transformed into a methionine form. The cofactors of this processes are folic acid, vitamin B12 and vitamin B6 [41]. Although homocysteine is an amino acid which source are products of animal origin, it is observed in elevated concentrations in the blood of people using vegetarian diets [5, 41]. Chetchowska et al. carried out a study at the Institute of Mother and Child in Warsaw, the aim of which was to assess the serum homocysteine concentration in children using the vegetarian diet compared to the control group, which was children using the traditional diet. The concentration of vitamins $\mathrm{A}$ and $\mathrm{E}$, the main antioxidants, was also checked. The concentration of antioxidants in the blood was lower in the vegetarian group. Nevertheless, homocysteine levels were similar in both groups and were within the norm [5]. Similar results were obtained by the Abroszkiewicz et al. [2].

Not all people, who apply vegetarian diets are aware of the fact that an incorrectly composed diet, especially the one consisting mainly of plant products, may not fully provide all nutrients. In a survey $(\mathrm{n}=100)$ carried out by Pyrzyńska, $84 \%$ of respondents confirmed this fact. Only $16 \%$ of subjects, most of whom were vegans, understand that without proper supplementation it is not possible to provide the right amount of nutrients [29]. In the study carried out by Śliwińska et al., over $80 \%$ of vegetarians and nonvegetarians $(n=76)$, stated that in the vegan diet supplementation is essential. Vegetarians most often supplemented vitamin B12 and vitamin D [35]. The same conclusions were drawn by Grzelak et al. The vast majority of vegetarians surveyed in this study $(n=47)$ used vitamin $D$ and vitamin B1 supplementation [10]. 
Table 1. Classification of vegetarian diets [35]

\begin{tabular}{|l|l|}
\hline \multicolumn{1}{|c|}{ Type of a vegetarian diet } & \multicolumn{1}{c|}{ Definition } \\
\hline Lacto-ovo-vegetarian diet & $\begin{array}{l}\text { Meat, poultry or fish are excluded, but all other animal products (e.g. eggs, } \\
\text { milk, honey) may be consumed }\end{array}$ \\
\hline Ovovegetarian diet & Includes eggs but excludes meat, poultry, fish and additionally dairy products \\
\hline Lacto-vegetarian diet & Includes dairy products but excludes meat, poultry, fish and additionally eggs \\
\hline Semi-vegetarian diet & Excludes only red meat from the diet \\
\hline Vegan diet & Excludes all products and preparations of animal origin \\
\hline Raw vegetarian diet & $\begin{array}{l}\text { The basis of this diet is the inclusion of vegetable products in raw form. No } \\
\text { heat treatment above } 40^{\circ} \mathrm{C} \text { and high processed foods are allowed }\end{array}$ \\
\hline Fruitarian diet & Only fruits are allowed \\
\hline
\end{tabular}

\section{HEALTH EFFECTS OF VEGETARIAN DIETS}

In 2012, Polish Institute of Food and Nutrition issued a statement regarding the use of vegetarian diets and explained that "correctly balanced vegetarian diets provide health benefits in the prevention and treatment of many diseases", including obesity, type II diabetes [15]. Lack of physical activity combined with an improperly balanced diet, consisting mainly of highly processed food and meals with the majority of fatty animal products is the main cause of overweight and obesity. The most effective fight against excessive body weight is a low energy density diet, as well as a lower content of fats, including saturated fatty acids and cholesterol. The best diet that meets the above requirements is a diet based mainly on plant products [38].

To confirm this fact, in 2013 at the Institute of Food and Nutrition in Warsaw, a study was carried out on 151 female subjects aged 45-65. Women were divided into two groups - one eating in a traditional way and a second vegetarian. Each of the female subjects underwent body composition analysis using the bioimpedance method (BIA). It was shown that BMI (Body Mass Index) in women using the traditional diet $(\mathrm{n}=86)$ was $30.1 \pm 5.7 \mathrm{~kg} / \mathrm{m} 2$, which indicated the first degree obesity. What's more, they were characterized by a much higher content of adipose and visceral fat. However, female subjects used the vegetarian diet $(\mathrm{n}=65)$, had normal BMI $\left(24.2 \pm 5.1 \mathrm{~kg} / \mathrm{m}^{2}\right)$. In addition to the body mass index, the content of total water, extracellular water, intracellular water, lean body mass, muscle mass and body fat mass were also determined. Among the above mentioned parameters, only muscle and body fat mass differ significantly between the two groups of subjects. Female subjects using a vegetarian diet were characterized by greater muscle mass and lower body fat mass compared to those who were nourished in the traditional way. The authors concluded that the parameters of the body composition of women on a vegetarian diet were more beneficial than those who nourished in a traditional way [32].
Many studies showed that weight loss is associated with a positive effect on glycemic control. The use of a vegetarian diet is related with a much lower amount of food rich in fat, especially saturated fatty acids. It leads to a reduction in the amount of glycated hemoglobin. In addition, high fiber intake in a vegetarian diet is associated with an increased satiety, and thus reduces the willingness to eat which is associated with risk of weight gain [16].

\section{DISEASES OF THE CARDIOVASCULAR SYSTEM AND VEGETARIAN DIETS}

Cardiovascular diseases are the biggest threat to Poles' lives, and thus constitute the main cause of mortality. For many years, almost half of all deaths in Poland have been caused by cardiovascular diseases. The most frequent mortality recorded is due to coronary heart disease, followed by myocardial infarction [6]. The most common cause of the development of cardiovascular diseases is persistent and untreated hypertension. Hypertension is recognized in the case of $140 \mathrm{mmHg}$ for systolic blood pressure (SBP) and $90 \mathrm{mmHg}$ for diastolic pressure (DBP) [9]. Śliż et al. suggest that the main way to treat hypertension is lifestyle modification, for example: limiting alcohol consumption, quitting smoking, reducing body mass, increasing physical activity and diet change [36].

In terms of changes in eating habits, the benefits of increased consumption of vegetables, vegetable protein and fiber are pointed out. It is also recommended to give up full-fat products of animal origin [36]. The daily intake of fat should not exceed $70 \mathrm{~g}$ [9]. Excessive intake of saturated fatty acids promotes the development of cardiovascular diseases. They increase the risk of developing overweight and obesity, which in turn are associated with hypertension, abnormal lipid profile and the process of atherosclerotic plaque formation. The source of saturated fatty acids is meat and animal fat. It is worth exchanging them for monounsaturated and polyunsaturated fatty acids, which are found in vegetable oils, as well as in marine fish, seeds and nuts [9]. It is claimed that the nuts should be consumed in an amount of about $30 \mathrm{~g} /$ day [14]. 
Table 2. The supply of minerals in the diet of vegetarians and non-vegetarians [18]

\begin{tabular}{|l|c|c|c|}
\hline \multicolumn{1}{|c|}{ Minerals } & \multicolumn{1}{|c|}{$\begin{array}{c}\text { Group of vegetarians } \\
(\mathrm{n}=15) \\
\mathrm{X} \pm \mathrm{SD}\end{array}$} & $\begin{array}{c}\text { Control group } \\
(\mathrm{n}=15) \\
\mathrm{X} \pm \mathrm{SD}\end{array}$ & $\mathrm{p}$-value \\
\hline Sodium $[\mathrm{mg}]$ & $1477 \pm 714$ & $1892 \pm 888$ & $\mathrm{p}>0.05$ \\
\hline Potassium $[\mathrm{mg}]$ & $3137 \pm 936$ & $2819 \pm 951$ & $\mathrm{p}>0.05$ \\
\hline Calcium $[\mathrm{mg}]$ & $911 \pm 400$ & $801 \pm 398$ & $\mathrm{p}>0.05$ \\
\hline Phosphorus $[\mathrm{mg}]$ & $1519 \pm 411$ & $1174 \pm 410$ & $\mathrm{p}<0.05$ \\
\hline Magnesium $[\mathrm{mg}]$ & $430 \pm 123$ & $278 \pm 98$ & $\mathrm{p}<0.05$ \\
\hline Iron $[\mathrm{mg}]$ & $23 \pm 11$ & $12 \pm 3$ & $\mathrm{p}<0.05$ \\
\hline Zinc $[\mathrm{mg}]$ & $13 \pm 8$ & $10 \pm 4$ & $\mathrm{p}>0.05$ \\
\hline Copper $[\mathrm{mg}]$ & $1.85 \pm 1.04$ & $1.09 \pm 0.48$ & $\mathrm{p}<0.05$ \\
\hline
\end{tabular}

$\overline{\mathrm{X}}$ - mean value, $\mathrm{SD}$ - standard deviation

The use of vegetarian diets brings positive effects both in the context of treatment of cardiovascular diseases as well as their prevention. As a good example of this is that vegetarian diets is associated with an effective improvement of the lipid profile. Panczenko-Kresowska et al. carried out a study on 170 vegetarians subjects who used lacto-ovo-vegetarian, lacto-vegetarian, vegan and semi-vegetarian diets and 80 subjects using a traditional diet. The best results were recorded for vegans, characterized by the lowest LDL and the highest HDL cholesterol, in comparison to the others. In other groups of vegetarians, better levels of lipid profile parameters were also observed when compared to those using the traditional diet [25]. Ambroszkiewicz et al. who assessed the relationship between the adipocytokines concentration and anthropometric parameters came to similar conclusions. The study was carried out on 30 children with a normal weight using a vegetarian diet, 30 children with a normal weight on a traditional diet and 30 obese children, also using a traditional diet. The nutritional diary of each child was assessed and total cholesterol, LDL and HDL cholesterol and triglycerides were measured. Children on a vegetarian diet gained energy mainly from carbohydrate-rich foods, while the other groups consumed significantly more fat-containing products. Vegetarian type of nutrition was associated with the lower concentrations of total cholesterol, LDL and triglycerides in the blood [1]. The results of this study showed that a vegetarian diet can help to reduce the risk of cardiovascular disease in adulthood.

\section{CONTROVERSY RELATED TO THE VEGETARIAN DIET}

There is a lot of controversy about a vegetarian diet, especially a vegan diet. Most people of Polish society still think, that this way of eating is incorrect, and it may cause undesirable health effects. Mainly people who have never used a vegetable diet claim that this way of nutrition should not be used by anyone [35].
Szczuko et al. carried out a study to check how the resignation from meat and animal origin products could change the quantities of individual components. They designed diets arranged in accordance with the principles of proper nutrition and modified them in accordance with the assumptions of the appropriate type of vegetarian diet: semi-vegetarian, lacto-ovovegetarian, ovovegetarian and vegan. An increase in the share of polyunsaturated fatty acids along with the elimination of meat and dairy products was observed. Researchers concluded that the more restrictive diet, the smaller the share of energy from proteins. In addition, they emphasize that a diet with a low supply of essential amino acids derived from food of animal origin may be contraindicated for athletes, while pregnant women may not get the recommended amount of nutrients necessary for proper development of a fetus [34].

To confirm the harmfulness of a poorly balanced diet on the state of the body, Herman [12] carried out a study to assess the impact of a vegetarian diet on the formation of tooth erosion. In the vegetarian group, there was a significantly larger number of losses than the group of non-vegetarians. This is mainly due to the higher intake of acid fruits and vegetables. Herman, in the other publication [11] assessed the effect of a vegetarian diet on the concentration of calcium, magnesium and carbonates in the saliva of vegetarians. It is mainly saliva responsible for maintaining homeostasis in the mouth. Calcium that penetrates into the saliva takes part in the process of remineralisation of teeth and prevents the demineralization of enamel. Salivary compositions were compared to the control group. The analysis showed that lower concentrations of magnesium and calcium were found in vegetarian vegetation [11]. Negative impact of the vegan diet on skeletal status is presented in the work by Ambroszkiewicz et al. [3]. The state of the skeletal system in vegans was assessed using densitometric and biochemical tests. At the same time, the concentrations of phosphates, which were at the 
appropriate level, as well as calcium and vitamin $\mathrm{D}$, for which deficiencies were noted, were determined. The researchers concluded that too low supply of vitamin D and calcium with the vegan diet may adversely affect the rate of bone metabolism and be associated with a decrease in bone mineral density [3].

The most controversial aspect related to the vegetarian diet is its use by pregnant women. OlejniczakNowakowska et al., tried to determine whether the use of vegetarian diet by pregnant women will not cause health disorders in them and their unborn babies. After analyzes of the results of over a dozen studies it was concluded that a properly balanced diet can be used by pregnant women because it fully provides the necessary nutrients and does not carry risks associated with disorders in the development of the fetus. It is also worth noting that the more restrictive vegetarian diet, the more important is the consultation with the physician, who carries out the pregnancy, as well as the dietician, in order to recommend the appropriate supplementation [22].

\section{CONCLUSIONS}

Vegetarians have a better chance to avoid the problem of obesity, development of cardiovascular disease than those who eat meat products. The absorption of a large amount of antioxidants, vitamins, minerals and the restriction of animal products can maintain a good state of health. However, vegetarians are exposed to deficiencies of vitamin B12 and D which in the long run may be associated with abnormal functioning of the body.

Vegetarians in Poland are not very well studied group. A large part of the researches are surveys and the analyzed groups are not too numerous. This review shows the need for further research on vegetarians and vegetarian diets, both in terms of diet-related diseases, i.e. diabetes, metabolic syndrome, obesity, and cardiovascular diseases, as well as consequences of some vitamins and minerals deficiencies.

\section{Conflict of interest}

The authors declare no conflict of interest.

\section{REFERENCES}

1. Ambroszkewicz J., Klemarczyk W., Gajewska J., Chetchowska M., Rawicak G., Ottarzewski M., LaskowskaKlita T.: Serum concentration of adypocytokines in prepubertal vegetarian and omnivorous children. Med Wieku Rozw 2011;15(3): 326-334

2. Ambroszkiewicz J., Klemarczyk W., Chetchowska M., Gajewska J., Laskowska-Klita T.: Serum homocysteine, folate, vitamin B1 and Total antioxidant status in vegetarian children. Adv Med Sci 2006; 51:265-268.
3. Ambroszkiewicz J., Klemarczyk W., Gajewska J., Chetchowska M., Franek E., Laskowska- Klita T.: The influence of vegan diet on bone mineral density and biochemical bone turnover markers. Pediatr Edocrinol 2010;16(3):201-204.

4. Chabasińska M., Przysławski J., Lisowska A., SchlegelZawadzka M., Grzymisławski M., Walkowiak J.: Typ i czas stosowania diety wegetariańskiej a surowicze stężenie witaminy B12. Prz Gastroenterol 2008;3(2):6366 (in Polish).

5. Chetchowska M., Ambroszkiewicz J., Klemarczyk W., Gajewska J., Ottarzewski M., Laskowska- Klita T.: Wpływ stosowania diety wegetariańskiej na stężenie homocyteiny oraz całkowitą aktywność przeciwutleniająca w surowicy u dzieci. Pol Merk Lek 2010;29(171):171-180 (in Polish).

6. Cierniak-Piotrkowska M., Marciniak G., Stańczak J.: Statystyka zgonów i umieralności z powodu chorób układu krążenia. W: Strzelecki Z., J. Szymborski, red. Zachorowalność i umieralność na choroby układu krążenia a sytuacja demograficzna Polski. Warszawa: Rządowa Rada Ludnościowa, 2015 (in Polish).

7. Czyżewska-Majchrzak Ł., Krzymińska-Siemaszko R., Pelczyńska M., Witmanowski H.: The benefits and risks of short-term diet changes on the example of the use a 5-week long lactoovovegetarian diet. Analysis of 7-day nutritional surveys of women - preliminary study. J Med Sci 2015;4(84):235- 243.

8. Drzycimska-Tatka B., Drab-Rybczyńska A., Kasprzak $J$. : Zespół Metaboliczny - Epidemia XXI wieku. Hygeia- Publ Health 2011;46(4):423-30 (in Polish).

9. Gibała M., Janowski G. J.: Znaczenie diety w prewencji oraz wyrównaniu nadciśnienia tętniczego. Chor Serca Naczyń, 2016; 13(4): 265-270 (in Polish).

10. Grzelak T., Suliga K., Pełczyńska M., Sperling M., Czyżewska K.: Ocena częstości stosowania suplementów diety wśród wegetarian oraz osób odżywiających się tradycyjnie. Probl Hig Epidemiolog 2017;98(2):170176 (in Polish).

11. Herman $K$.: Influence od vegetarian diet on calcium, magnesium and carbonate level in saliva. Dent Med Robl 2007; 44(2):172- 176.

12. Herman K.: Wpływ diety wegetariańskiej na występowanie erozji zębów. Dent Med Probl 2005;42(3):457463 (in Polish).

13. Historia wegetarianizmu i weganizmu. Available https://proveg.com/pl/blog/historia-wegetarianizmu-weganizmu/ (21.02.2019).

14. Jankowski P.: Zasady profilaktyki chorób układu krążenia w 2018 roku. Kardiol Inwazyjna 2017;12(6):42-48 (in Polish).

15. Jarosz M.: Odpowiedź na petycje w sprawie umożliwienia rodzicom wyboru diety wegetariańskiej lub wegańskiej w publicznych placówkach oświatowych. Instytut Żywności i Żywienia, pismo z 12.11.2012 r. (in Polish).

16. Jarosz M., Siuba M., Karwowska K.: Znaczenie diety wegetariańskiej w prewencji i leczeniu cukrzycy typu 2 u osób otyłych. Żyw Człow 2011;38(2):136- 143 (in Polish). 
17. Jastrzębowski J.: Historja ruchu jarskiego w Polsce. Hygieia, 1912 (in Polish).

18. Król E., Sobiech M., Krejpcio Z.: Ocena spożycia składników mineralnych w całodziennych racjach pokarmowych wybranej grupy wegetarian i niewegetarian. Żywn Nauka Technol Jakość 2005;2(43):114-120 (in Polish).

19. Madry E., Lisowska A., Grebowiec P., Walkowiak J.: The impast of vegan diet on B-12 status in health omnivores: five- year prospective study. Acta Sci Pol Technl Aliment 2012;11(2):209-213.

20. Millenialsi lubą zdrowo jeść; rośnie liczba wegetarian, wegan i fleksiwegetarian. Available http://www.portalspozywczy.pl/handel/wiadomosci/millenialsi-lubia-zdrowo-jesc-rosnie-liczba-wegetarian-wegan-i-fleksitarian, 140400.html (21.02.2019).

21. Nazarewicz R.: Wpływ stosowania diety wegetariańskiej na wybrane parametry morfologiczne i biochemiczne krwi. [The effect of vegetarian diet on selected biochemical and blood morphology parameters ]. Rocz Panstw Zakl Hig 2007;58(1):23-27 (in Polish).

22. Olejniczak-Nowakowska M., Krupa- Kotara K., Krasowski G., Grochowska Ż., Mazur M.: Vegetarian diet observed by pregnant women. Benefits and risks for mother and fetus. Ann Acad Med Siles 2018;72:45-52.

23. Olędzki R.: Potencjał antyoksydacyjny owoców i warzyw oraz jego wpływ na zdrowie człowieka. Nauki Inż Tech 2012,1(4):44-54 (in Polish).

24. Pacholczyk M., Ferenc T., Kowalski J.: Zespół metaboliczny. Część I : Definicje i kryteria rozpoznawania zespołu metabolicznego. Epidemiologia oraz związek z ryzykiem chorób sercowo-naczyniowych i cukrzycy typu. Postępy Hig Med Dosw 2008;62:530-542 (in Polish).

25. Panczenko-Krasowska B., Ziemlański Ś.: The effects of vegetarian mode of nutrition on plasma lipids and peroxidation processes. Plasma lipids in vegetarians. Part I. Żyw Człow 1995;22(3):207- 219.

26. Pawlak J., Derlacz R. A.: Mechanizm powstawania oporności na insulinę w tkankach obwodowych. Post Bioch 2011;57(2):200-206 (in Polish).

27. Polskie Towarzystwo Diabetologiczne: Zalecenia kliniczne dotyczące postępowania u chorych na cukrzycę 2018;4 (in Polish).

28. Przybylska D., Kurkowska M., Przybylski P.: Otyłość i nadwaga w populacji rozwojowej. Hygeia-Publ Health 2012;47(1):28-35 (in Polish).

29. Pyrzyńska E.: Dieta wegetariańska w świetle zasad prawidłowego odżywiania- postawy i zachowanie wegetarian w Polsce. Zesz Nauk UEK 2013;906:27-36 (in Polish).

30. Sicińska E., Cholewa M.: Ocena potrzeb i możliwości zwiększenia zawartości witaminy B12 w diecie. Rocz Państw Zakł Hig 2012;63(1):67-71 (in Polish).
31. Stolińska H., Czerwonogrodzka-Senczyna A.: Ocena diety wegetariańskiej stosowanej u dzieci za pomocą wskaźnika alternatice health heating index (AHEI). Żyw Człow 2011;38(5):326-339 (in Polish).

32. Stolińska H., Wolańska D.: Analiza składu ciała kobiet na diecie tradycyjnej i wegetariańskiej. Żyw Człow 2015; 42(2):13-21 (in Polish).

33. Suliburska I., Kuśnierek J.: Czynniki żywieniowe i pozażywieniowe w rozwoju insulinooporności. Forum Zab Metabol 2010;1(3):177-183 (in Polish).

34. Szczuko M., Komorniak N., Hołowko J., Kinowska K., Jasińska A., Kowalska K.: Zmiana zawartości składników odżywczych, cholesterolu i błonnika w dietach eliminujących produkty pochodzenia zwierzęcego. Część I - makroskładniki. Pomeranian J Life Sci 2018;64(3):94-104 (in Polish).

35. Śliwińska A., Olszówka M., Pieszko M: Ocena wiedzy na temat diet wegetariańskich wśród populacji trójmiejskiej. Zesz Nauk Akad Morsk Gdyn 2014; 86:133-146 (in Polish).

36. Śliż D., Folga A.: Dieta wegetariańska- nowa moda czy przepis na leczenie nadciśnienia tętniczego? Kardiol Prakt 2014;8(1):31-33 (in Polish).

37. Śliż D., Mamcarz A.: Czy leczyć statynami wegetarian? Kardiol Dypl 2015;14: 15-18 (in Polish).

38. Śliż D., Zgliczyński W. S., Szeligowska J., Rostkowska O., Pinkas J.: Modyfikacja zwyczajów żywieniowych w prewencji chorób cywilizacyjnych. Post Nauk Med 2016;5:344-349 (in Polish).

39. Traczyk I., Ziemlański Ś.: Porównanie wartości odżywczej racji pokarmowych wegetarian i osób żywiących się tradycyjnie. Żyw Człow 2000;27(1):55-67 (in Polish).

40. Wesołowski P., Wańkowicz Z.: Insulinooporność- metody rozpoznawania i następstwa kliniczne. Nefrol Dial Pol 2010;15:243-246 (in Polish).

41. Winczewska-Wiktor A., Malendowicz-Major B., Steinborn B.: Rola homocysteiny w fizjologicznym rozwoju patofizjologii zaburzeń układu nerwowego u dzieci. Neurol Dziec 2012;21(42):11-21 (in Polish).

42. Włodarek D., Głąbska D.: Spożycie warzyw i owoców przez chorych na cukrzycę typu 2. Via Med 2010;11(6):221-229 (in Polish).

43. Wyniki badania Instytutu Badania Opinii Homo Homini dla Lightbox, wrzesień 2013. Available at: https:// www.lightbox.pl/poradnik-lightbox/zdrowe-odzywianie/wyniki-badania-instytutu-badania-opinii-homo-homini-dla-lightbox-wrzesien-2013 (21.02.2019)

Received: 29.04.2019

Accepted: 19.06.2019

This article is available in Open Access model and licensed under a Creative Commons Attribution-Non Commercial 3.0.Poland License (CC-BY-NC) available at: http://creativecommons.org/licenses/by-nc/3.0/pl/deed.en 